\title{
C766T low-density lipoprotein receptor-related protein 1 (LRP1) gene polymorphism and susceptibility to breast cancer
}

\author{
Petr Beneš ${ }^{1}$, Michal Jurajda², Jan Žaloudík ${ }^{3}$, Lydie Izakovičová-Hollá ${ }^{2}$ and Jiří Vácha ${ }^{2}$ \\ ${ }^{1}$ Department of Molecular Biology and Genetics, Faculty of Science, Masaryk University, Brno, Czech Republic \\ ${ }^{2}$ Department of Pathological Physiology, Faculty of Medicine, Masaryk University, Brno, Czech Republic \\ ${ }^{3}$ Masaryk Memorial Cancer Institute, Brno, Czech Republic \\ Corresponding author: Michal Jurajda (e-mail: mjuraj@med.muni.cz)
}

Received: 21 Jan 2003 Revisions requested: 18 Feb 2003 Revisions received: 25 Feb 2003 Accepted: 28 Feb 2003 Published: 14 Mar 2003

Breast Cancer Res 2003, 5:R77-R81 (DOI 10.1186/bcr591)

(C) 2003 Beneš et al., licensee BioMed Central Ltd (Print ISSN 1465-5411; Online ISSN 1465-542X). This is an Open Access article: verbatim copying and redistribution of this article are permitted in all media for any purpose, provided this notice is preserved along with the article's original URL.

\begin{abstract}
Background: Low-density lipoprotein receptor-related protein 1 (LRP1) is a multifunctional endocytic receptor with an important role in regulating the activity of proteinases in extracellular matrix. Several studies have also described its role in intracellular signaling. Previous studies showed that the expression of LRP1 is related to invasiveness of cancer cells. However, recent data on LRP1 suggest that this receptor can also be involved in tumor establishment and progression.
\end{abstract}

Methods: We investigated an association between the C766T polymorphism of the third exon of the $L R P 1$ gene and breast cancer in a sample of women of Caucasian origin. Allele and genotype frequencies of this polymorphism were assessed in
164 women with breast cancer and in 183 age-compatible women without a history of any cancer disease.

Results: An increase in LRP1 Tallele frequency in subjects with breast cancer was observed compared with controls $(0.21$ versus $0.15, P=0.01963)$. A significant excess of genotypes with the $T$ allele (homozygotes plus heterozygotes) was also observed (odds ratio 1.743, 95\% confidence interval 1.112-2.732).

Conclusion: The $T$ allele of the C766T polymorphism in the $L R P 1$ gene is associated with an increased risk of breast cancer development in women of Caucasian origin.

Keywords: breast cancer, case-control study, genetic polymorphism, low-density lipoprotein receptor-related protein 1

\section{Introduction}

The low-density lipoprotein receptor-related protein 1 (LRP1, ID 6692 in the Human Gene Nomenclature database) is a member of the low-density lipoprotein receptor (LDLR) family [1]. Receptors of this family mediate the internalization of a variety of extracellular macromolecules and macromolecular complexes, including lipoproteins, proteinases, proteinase-inhibitor complexes and extracellular matrix proteins [2]. Recent studies have demonstrated that several receptors of this family are also involved in ligand-mediated signal transduction [3].

LRP1 is a large endocytic receptor that recognizes more than 30 different ligands. Proteinases and molecules associated with the regulation of proteolytic activity are the largest group of LRP1 ligands. Certain proteinases bind directly to LRP1, whereas several other proteinases only bind once complexed with their specific inhibitors [2]. LRP1 is involved in the tight regulation of serine proteinases of the plasminogen/plasmin system and also in the regulation of certain matrix metalloproteinase family members $[1,4,5]$. Through the regulation of extracellular proteolytic activity, LRP1 has an important role in the regulation of cellular growth, cell migration, tissue repair and remodeling, and tumor progression and invasion $[1,3,6]$.

In addition, it has been shown that LRP1 is a signaling receptor involved in inositol and Wnt signaling, Ras activation and the activation of Src, mitogen-activated protein kinases and protein kinase A. Although the function of

$\mathrm{JNK}=\mathrm{c}$-Jun amino-terminal kinase; LRP1 $=$ low-density lipoprotein receptor-related protein $1 ;$ LDLR $=$ low-density lipoprotein receptor; PCR $=$ polymerase chain reaction; UPA = urokinase plasminogen activator. 
LRP1 in these processes is less well understood, several authors have suggested that LRP1 might modulate mitogenic signaling, cell adhesion, cell proliferation and apoptosis $[3,7,8]$.

Besides the role of LRP1 in protease regulation and cell signaling, Binder and colleagues [9] also suggested that it acts, through the binding of the heat shock protein gp96 on the surface of antigen-presenting cells, as a sensor for necrotic cell death leading to proinflammatory immune responses.

Because of its potential role in processes mentioned above, the relationship between LRP1 expression and cancer establishment, progression and invasion has been studied. Increased expression of LRP1 has been shown in human malignant astrocytes and the glioblastoma cell line U87 [10,11]. In addition, Li and colleagues [6] observed that LRP1 promotes invasiveness of breast cancer cells in vitro. However, previous studies also showed that LRP1 expression decreases with aggressiveness in several human tumor cell lines (lung carcinoma, osteosarcoma) compared with nontumor cell lines [12,13].

In addition, $L R P 1$ gene amplification has been observed in some astrocytomas [14], and Grimsley and colleagues [15] reported that the concentration of LRP1 protein increases with the passage number of cultured Hep G2 hepatoma cells, possibly owing to the selection of cells with $L R P 1$ gene amplification. Another interesting finding has recently been observed $[16,17]$ : in these papers it was suggested that $\angle R P 1 B$, a member of the LDLR family with striking homology to $L R P 1$, represents a tumor suppressor gene in non-small cell lung cancer cell lines [16] and urothelial cancer cells [17]. In their studies the authors reported frequent alteration of the $\angle R P 1 B$ gene in non-small cell lung cancer cell lines and urothelial cancer cells, respectively.

The common silent C766T polymorphism in exon 3 of the $L R P 1$ gene has been associated with Alzheimer's disease $[18,19]$, suggesting that this polymorphism might be of functional importance or might be a marker of other functional changes located in this gene. Our study was undertaken to investigate an association between the C766T $L R P 1$ polymorphism and the occurrence of breast cancer in a sample of Czech women of Caucasian origin.

\section{Materials and methods Subjects}

The populations tested comprised 164 females diagnosed with breast cancer (mean age 57 years, range 35-80 years), as a control population, and 183 age-compatible female volunteers (mean age 57 years, range 40-94 years) with no history of cancer of any type. The several oncologists and surgeons in the city of Brno, Czech Republic. All cancers were confirmed histologically. The control subjects were also recruited from several districts of the city of Brno by general practitioners from their clientele. Both the patients and the controls were unrelated Caucasians of Czech nationality. The study was approved by the Committee for Ethics of Medical Experiments on Human Subjects, Medical Faculty, Masaryk University, Brno.

\section{Methods}

Genomic DNA was extracted from peripheral blood leukocytes. The LRP1 C766T genotypes were determined by polymerase chain reaction (PCR) and a subsequent restriction analysis with $R$ sal restriction endonuclease as described by Hollenbach and colleagues [19]. PCR was performed in a total volume of $25 \mu$ l containing $50 \mathrm{ng}$ of genomic DNA, $10 \mathrm{pmol}$ of each primer (5'GGGGTCCAGGACTGCATGTA-3' and 5'-AAGTCCGTACCTCGGCAGTG-3'), $1 \times$ reaction buffer $(\mathrm{MBI}$ Fermentas, Vilnius, Lithuania), $200 \mu \mathrm{M}$ deoxyribonucleotides (Roche Diagnostics, Mannheim, Germany), $3.0 \mathrm{mM} \mathrm{Mg}^{2+}$ and 0.2 units of Taq polymerase (Fermentas). The amplification conditions were as follows: initial denaturation at $95^{\circ} \mathrm{C}$ for $3 \mathrm{~min}$, followed by 34 cycles of denaturation at $94^{\circ} \mathrm{C}$ for $30 \mathrm{~s}$, annealing at $54^{\circ} \mathrm{C}$ for $30 \mathrm{~s}$, elongation at $72^{\circ} \mathrm{C}$ for $20 \mathrm{~s}$ and final elongation at $72^{\circ} \mathrm{C}$ for 2 min. PCR products were digested with 5 units of Rsal (Fermentas). Digested fragments were separated on 4.0\% MetaPhor agarose gels and detected by ethidium bromide staining. The presence of the $T$ allele was characterized by fragments of 51 and 8 base pairs, the presence of the $C$ allele by fragments of 32,19 and 8 base pairs.

\section{Statistical analysis}

Differences in genotype distributions from those expected for Hardy-Weinberg equilibrium were tested by the $\chi^{2}$ test. The significances of differences in allele frequencies among groups were tested by Fisher's exact test. Odds ratios and 95\% confidence intervals were calculated. $P<0.05$ was considered statistically significant. For all statistical analyses, the data analysis software system STATISTICA, version 6 (StatSoft, Inc; www.statsoft.com) was used.

\section{Results}

Allele frequencies and genotype distribution of the C766T $L R P 1$ polymorphism in the breast cancer and the control groups are shown in Table 1. The distribution of genotypes in the breast cancer and the control groups did not differ from Hardy-Weinberg equilibrium. The distribution of alleles in the control group is identical with that previously reported in control subjects from the same Caucasian population [20]. The LRP1 $T$ allele frequency was significantly higher in women with breast cancer than in the control subjects $(0.21$ versus $0.15 ; P=0.01963)$. The 
Table 1

\begin{tabular}{|c|c|c|c|c|c|c|c|}
\hline \multirow[b]{2}{*}{ Group } & \multirow[b]{2}{*}{$n$} & \multicolumn{3}{|c|}{ Genotypes } & \multicolumn{2}{|c|}{ Allele frequencies } & \multirow[b]{2}{*}{$P$} \\
\hline & & $\mathrm{CC}$ & $C T$ & $T T$ & C & $T$ & \\
\hline Controls & 183 & 132 & 47 & 4 & 0.85 & 0.15 & \\
\hline Breast cancer & 164 & 98 & 62 & 4 & 0.79 & 0.21 & 0.01963 \\
\hline
\end{tabular}

combined number of subjects with the $T$ allele (CT heterozygotes and $T T$ homozygotes) was significantly higher in the breast cancer subjects than in the controls (odds ratio $1.743,95 \%$ confidence interval 1.112-2.732).

\section{Discussion}

Tumorigenesis is a multistep process that involves cell transformation, invasive growth, angiogenesis and spread of the tumor into distant sites [21]. It has previously been suggested that LRP1 is involved in the regulation of some of these processes.

The breakdown of the basement membrane and extracellular matrix facilitates cancer cell invasion and migration into the surrounding normal tissues [22]. This critical step in cancer progression is mediated by serine proteinases and metalloproteinases [23]. It has been demonstrated that LRP1 modulates the extracellular levels of several matrix metalloproteinases $[4,5]$ as well as the extracellular level of urokinase plasminogen activator (uPA), a serine proteinase that activates plasminogen [2]. Extracellular proteolytic activity is an important factor in cancer establishment and progression [24-26]. However, recent studies indicate that proteinases participate not only in cancer progression and metastasis but that they are important in all stages of tumorigenesis including tumor establishment, growth and neovascularization [25]. Degradation of the extracellular matrix mediated by these proteinase systems perturbs cellular signaling, interferes with the adhesiveness of cells and activates several growth factors, all of which processes are important in tumorigenesis [25-27].

Lutz and colleagues [7] have recently shown that LRP1 modulates the mitogen-induced c-Jun amino-terminal kinase (JNK) signaling pathway and therefore the transcriptional activity of the transcription factor activator protein 1 (AP-1), which has been implicated in a variety of biological processes including cell proliferation, apoptosis and oncogenic transformation [28]. Moreover, Lutz and colleagues found that the expression of a fusion protein bearing the intracellular carboxy-terminal tail of human LRP1 and the transmembrane region plus the extracellular $\lg \mathrm{G}-\mathrm{F}_{\mathrm{c}}$ domain selectively reduced DNA-damage-induced apoptosis in neuronal cells. The authors suggested that LRP1 is involved, by modulating the JNK signaling transduction pathway, in apoptotic and stress responses [7].

JNK lies downstream in the Ras signaling pathway. Ras proteins are key transducers of growth signals regulated by receptors on the cell surface [29]. Recent studies have shown that the phosphorylated cytoplasmic tail of LRP1 associates both in vivo and in vitro with the cellular docking protein Shc [30]. It has been suggested that this association is important for the phosphorylation of Shc. Phosphorylated Shc proteins are important mediators of Ras activation. Phosphorylation of tyrosine residues of LRP1 is thus believed to be involved in signal transduction. The role of LRP1 in other types of cell signaling has been also suggested $[3,8]$.

Our study was designed to investigate the role of C766T $L R P 1$ polymorphism in breast cancer development. We observed that the LRP1 $T$ allele frequency was significantly higher in patients with breast cancer than in the age and sex-compatible control subjects. These findings imply that female bearers of the LRP1 T allele are more susceptible to breast cancer development than women with the LRP1 CC genotype. However, large studies will be needed to confirm this finding.

We are aware that association studies have several limitations. The heterogeneity between patients and control subjects in terms of age and ethnicity could explain false positive results. Moreover, small population-based samples might not be representative in terms of the allele and genotype frequencies of whole population. However, it seems that this is not true of this study. Patient and control subjects were age-compatible unrelated Caucasians recruited from a homogenous Czech population. Moreover, the LRP1 Tallele frequency of the control group from this study is almost identical with that previously observed in a large sample of subjects from the same Caucasian population [20]. The fact that allele and genotype frequencies in all samples studied did not differ from Hardy-Weinberg equilibrium also suggests that the observed allele and genotype frequencies are representative of the Czech population. 
Previous reports suggested that LRP1 promotes invasiveness of breast cancer cells in vitro [6] and that the expression of LRP1 in human breast cancer cells is induced by hypoxia [31], estrogen and cell density [32]. In addition, Chazaud and colleagues [33] reported that UPA and LRP1 are localized at filopodia of invasive breast cancer cells, and that the formation/internalization of a complex of LRP1 with UPA, UPA receptor and plasminogen activator inhibitor- 1 is required for the attachment and migration of cancer cells in vitro.

So far, little is known about the functional importance of the silent C766T LRP1 polymorphism. Numerous studies have associated this polymorphism with an increased risk of Alzheimer's disease $[18,19]$ suggesting that this polymorphism is probably a marker of other functional changes located in this gene. However, although the C766T polymorphism causes neither an amino acid change nor an alteration of a consensus splicing site, we cannot discount the C766T variant as a neutral polymorphism. A functional $L R P 1$ polymorphism could (1) influence the expression of the LRP1 gene and thus the number of LRP1 receptors on the cell surface, (2) influence the affinity of LRP1 for its ligands and thus the uptake of several proteases and their inhibitors, and (3) alter the signaling activity of LRP1. The exact role of the $\mathrm{C} 766 \mathrm{~T}$ polymorphism in $\angle R P 1$ remains to be resolved.

\section{Conclusion}

The results of this study indicate that the $T$ allele of the C766T polymorphism in the LRP1 gene is associated with an increased risk of breast cancer development in female Caucasian subjects. Further studies are needed to establish an influence of this and other LRP1 polymorphisms on $L R P 1$ gene expression and/or protein function. The role of LRP1 polymorphisms in other types of cancer also remains to be solved.

\section{Competing interests}

None declared.

\section{Acknowledgements}

Recruitment of patients and control subjects was made in co-operation with Dr D Macková, Dr I Kocáková and Dr O Bednařik. Excellent technical assistance from Ms Tereza Vávrová, Ms Andrea Stejskalová and Ms Anna Pekárková is gratefully acknowledged. This study was supported by grant CEZ J07/98:141100002 from the Ministry of Education, Youth and Physical Training of the Czech Republic.

\section{References}

1. Strickland DK, Kounnas MZ, Williams SE, Argraves WS: LDL receptor-related protein (LRP1): a multiligand receptor. Fibrinolysis 1994, 8:204-215.

2. Kasza A, Petersen HH, Heegaard CW, Oka K, Christensen A, Dubin A, Chan L, Andreasen PA: Specifity of serine proteinase/ serpin complex binding to very-low-density lipoprotein receptor and $\alpha 2$-macroglobulin receptor/low-density-lipoproteinreceptor-related protein. Eur J Biochem 1997, 248:270-281.

3. Herz J, Strickland DK: LRP1: a multifunctional scavenger and signaling receptor. J Clin Invest 2001, 108:779-784.
4. Barmina OY, Walling HW, Fiacco GJ, Freije JM, Lopez-Otin C, Jeffrey JJ, Partridge NC: Collagenase-3 binds to a specific receptor and requires the low density lipoprotein receptorrelated protein for internalization. J Biol Chem 1999, 274: 30087-30093.

5. Yang Z, Strickland DK, Bornstein P: Extracellular matrix metalloproteinase 2 levels are regulated by the low density lipoprotein-related scavenger receptor and thrombospondin 2. J Biol Chem 2001, 276:8403-8408.

6. Li Y, Wood N, Grimsley P, Yellowlees D, Donnelly PK: In vitro invasiveness of human breast cancer cells is promoted by low density lipoprotein receptor-related protein. Invasion Metastasis 1998, 18:240-251.

7. Lutz C, Nimpf J, Jenny M, Boecklinger K, Enzinger C, Utermann G, Baier-Bitterlich G, Baier G: Evidence of functional modulation of the MEKK/JNK/cJun signaling cascade by the low density lipoprotein receptor-related protein (LRP1). J Biol Chem 2002, 277:43143-43151.

8. van der Geer P: Phosphorylation of LRP11: regulation of transport and signal transduction. Trends Cardiovasc Med 2002, 12: 160-165.

9. Binder RJ, Han DK, Srivastava PK: CD91: a receptor for heat shock protein gp96. Nat Immunol 2000, 1:151-155.

10. Yamamoto M, Ikeda K, Oshshima K, Tsugo H, Kimura H, Tomonaga M: Increased expression of low density lipoprotein receptor-related protein/ $\alpha 2$-macroglobulin receptor in human malignant astrocytomas. Cancer Res 1997, 57:2799-2805.

11. Bu G, Maksymovitch EA, Geuze H, Schwartz AL: Subcellular localization and endocytic function of low density lipoprotein receptor-related protein in human glioblastoma cells. J Biol Chem 1994, 269:29874-29882.

12. Van Leuven F, Cassiman JJ, Van den Berghe H: Demonstration of an $\alpha 2$-macroglobulin receptor in human fibroblasts, absent in tumor-derived cell lines. J Biol Chem 1979, 254:5155-5160.

13. Saksela $O$, Wahström $T$, Lehtovirta $P$, Seppälä M, Vaheri A: Presence of $\alpha 2$-macroglobulin in normal but not in malignant syncytiotrophoblasts. Cancer Res 1981, 41:2507-2513.

14. Baum L, Dong ZY, Choy KW, Pang CP, Ng HK: Low density lipoprotein receptor related protein gene amplification and 766T polymorphism in astrocytomas. Neurosci Lett 1998, 256: 5-8.

15. Grimsley PG, Quinn KA, Chesterman CN, Owensby DA: Low density lipoprotein receptor-related protein (LRP1) expression varies among Hep G2 cell lines. Thromb Res 1997, 88: 485-498.

16. Liu CX, Musco S, Lisitsina NM, Yaklichkin SY, Lisitsyn NA: Genomic organization of a new candidate tumor suppressor gene, LRP11B. Genomics 2000, 69:271-274.

17. Langbein $S$, Szakacs $O$, Wilhelm M, Sukosd F, Weber $S$, Jauch $A$, Lopez Beltran A, Alken P, Kalble T, Kovacs G: Alteration of the LRP11B gene region is associated with high grade of urothelial cancer. Lab Invest 2002, 82:639-643.

18. Kang DE, Saitoh T, Chen X, Masliah E, Hansen LA, Thomas RG, Thal LJ, Katzman R: Genetic association of the low-density lipoprotein receptor-related protein gene (LRP1), an apolipoprotein E receptor, with late-onset Alzheimer's disease. Neurology 1997, 49:56-61.

19. Hollenbach E, Ackerman S, Hyman BT, Rebeck W: Confirmation of an association between a polymorphism in exon 3 of the low-density lipoprotein receptor-related protein gene and Alzheimer's disease. Neurology 1998, 50:1905-1907.

20. Beneš P, Muzík J, Benedík J, Elbl L, Vašku A, Šišková L, Znojil V, Vácha J: The C766T low-density lipoprotein receptor-related protein polymorphism and coronary artery disease, plasma lipoproteins and longevity in Czech population. $J \mathrm{Mol}$ Med 2001, 79:116-120.

21. Hanahan D, Weinberg RA: The hallmarks of cancer. Cell 2000, 100:57-70.

22. Liotta LA, Steeg PS, Stetler-Stevenson WG: Cancer metastasis and angiogenesis: an imbalance of positive and negative regulation. Cell 1991, 64:327-336.

23. Danø K, Andreasen PA, Grondahl-Hansen K, Kristensen $P$ Nielsen LS, Skriver L: Plasminogen activators, tissue degradation and cancer. Adv Cancer Res 1985, 44:139-266.

24. Danø K, Rømer J, Nielsen BS, Bjørn S, Pyke C, Rygaard J, Lund LR: Cancer invasion and tissue remodeling - cooperation of protease systems and cell types. APMIS 1999, 107:120-127. 
25. McCawley L, Matrisian LM: Matrix metalloproteinases: multifunctional contributors to tumor progression. Mol Med Today 2000, 6:149-156.

26. Cuzner ML, Opdenakker G: Plasminogen activators and matrix metalloproteases, mediators of extracellular proteolysis in inflammatory demyelination of the central nervous system. $J$ Neuroimmunol 1999, 94:1-14.

27. Bergers G, Coussens LM: Extrinsic regulators of epithelial tumor progression: metalloproteinases. Curr Opin Genet Dev 2000, 10:120-127.

28. Shaulian $E$, Karin M: AP-1 in cell proliferation and survival. Oncogene 2001, 20:2390-2400.

29. Macaluso M, Russo G, Cinti C, Bazan V, Gebbia N, Russo A: Ras family genes: an interesting link between cell cycle and cancer. J Cell Physio/ 2002, 192:125-130.

30. Barnes $H$, Larsen B, Tyers M, van der Geer P: Tyrosine-phosphorylated low density lipoprotein receptor-related protein 1 (LRP11) associates with the adaptor protein SHC in SRCtransformed cells. J Biol Chem 2001, 276:19119-19125.

31. Koong AC, Denko NC, Hudson KM, Schindler C, Swiersz L, Koch C, Evans S, Ibrahim L, Le QT, Terris DJ, Giaccia AJ: Candidate genes for the hypoxic tumor phenotype. Cancer Res 2000, 60: 883-887.

32. Li Y, Wood N, Donnelly P, Yellowlees D: Cell density and oestrogen both stimulate alpha 2-macroglobulin receptor expression in breast cancer cell T-47D. Anticancer Res 1998, 18:1197-1202.

33. Chazaud B, Ricoux R, Christov C, Plonquet A, Gherardi RK Barlovatz-Meimon G: Promigratory effect of plasminogen activator inhibitor-1 on invasive breast cancer cell populations. Am J Pathol 2002, 160:237-246.

\section{Correspondence}

Michal Jurajda, Department of Pathophysiology, Faculty of Medicine, Masaryk University, Komenského nám. 2, 66243 Brno, Czech Republic. Tel: +420 542 126 547; fax: +420 542126 550; e-mail: mjuraj@med.muni.cz 